\title{
PERAN ILMU KEDOKTERAN FORENSIK DALAM PEMBUKTIAN TINDAK PIDANA PEMERKOSAAN SEBAGAI KEJAHATAN KEKERASAN SEKSUAL
}

\author{
Amelia Kalangit \\ J. Mallo \\ D. Tomuka
}

\author{
${ }^{1}$ Kandidat Skripsi Fakultas Kedokteran Universitas Sam Ratulangi Manado \\ ${ }^{2}$ Bagian Forensik Fakultas Kedokteran Universitas Samratulangi Manado
}

\begin{abstract}
Rape is a serious crime and a violation of human rights. The act of rape causes serious psychological trauma to the victims and families. According to the National Commission on Violence Against Women (Komnas Perempuan) from 1998 to 2010 almost one third of cases of violence against women is a case of sexual assault, or sexual assault cases recorded 91,311 of 295,836 total cases of violence against women. During 2010 there were 1751 victims of sexual violence. Rape is an event that is difficult to prove even though the case has been examined and evidence gathering is complete. In an effort to prove that there has been crime of rape, then in this case Forensic Science was an instrument in conducting the examination and to obtain an explanation for what happened medically. This study aims to determine the management of Forensic Science in the proof of criminal rape. To know the legal and medical aspects of Forensic Science in the proof of crimes of sexual violence.
\end{abstract}

Keywords - forensic science, sexual assault, rape.

Abstrak - Perkosaan merupakan kejahatan yang serius dan bukti pelanggaran Hak Asasi Manusia (HAM). Tindakan perkosaan menyebabkan trauma psikologis yang serius pada korban serta keluarga. Menurut Komisi Nasional Anti Kekerasan Terhadap Perempuan (Komnas Perempuan) sejak tahun 1998 hingga 2010 hampir sepertiga kasus kekerasan terhadap perempuan adalah kasus kekerasan seksual, atau tercatat 91.311 kasus kekerasan seksual dari 295.836 total kasus kekerasan terhadap perempuan. Selama 2010 tercatat 1.751 korban kekerasan seksual. Perkosaan merupakan suatu peristiwa yang sulit dibuktikan walaupun pada kasus tersebut telah dilakukan pemeriksaan dan pengumpulan barang bukti yang lengkap. Dalam upaya pembuktian hukum bahwa telah terjadi tindak pidana perkosaan, maka dalam hal ini Ilmu Kedokteran Forensik sangat berperan dalam melakukan pemeriksaan dan untuk memperoleh penjelasan atas peristiwa yang terjadi secara medis. Penelitian ini bertujuan untuk mengetahui penatalaksanaan Ilmu Kedokteran Forensik dalam pembuktian tindak pidana pemerkosaan. Untuk mengetahui segi hukum dan medis Ilmu Kedokteran Forensik dalam pembuktian kasus kejahatan kekerasan seksual.

Kata kunci - forensic science, sexual assault, rape.

Perkosaan merupakan kejahatan yang serius dan bukti pelanggaran Hak Asasi Manusia (HAM). Tindakan perkosaan menyebabkan trauma psikologis yang serius pada korban serta keluarga. Mengingat apa yang dilakukan pelaku 
telah mengakibatkan munculnya berbagai persoalan buruk yang dihadapi oleh korban dan juga mengakibatkan ketakutan pada masyarakat (fear of society). ${ }^{1}$

Pemerkosaan adalah suatu tindakan kekerasan, bukan seksual karena suka sama suka. Sangat banyak klasifikasi psikologi yang telah diusulkan untuk mengkarakteristik perkosaan, tapi perubahan psikodinamik pada korban yang terlibat dalam seluruh skema meliputi feelings of inadequacy, kemarahan yang tidak tersalurkan (misalnya, impulse control disorders), atau penyimpangan gangguan karakter lain. $^{2}$

Menurut Komisi Nasional Anti Kekerasan Terhadap Perempuan (Komnas Perempuan) sejak tahun 1998 hingga 2010 hampir sepertiga kasus kekerasan terhadap perempuan adalah kasus kekerasan seksual, atau tercatat 91.311 kasus kekerasan seksual dari 295.836 total kasus kekerasan terhadap perempuan. Selama 2010 tercatat 1.751 korban kekerasan seksual. ${ }^{3}$

Pasien-pasien yang datang ke bagian gawat darurat sesudah kekerasan seksual memberikan tantangan khusus bagi dokter yang menanganinya. Pasien mungkin malu atau tidak ingin mengingat kembali riwayat peristiwa yang dialami, ketepatan waktu dalam mengumpulkan data riwayat peristiwa sangat penting untuk penanganan tepat waktu dan dokumentasi forensik. $^{4,5}$

Perkosaan merupakan suatu peristiwa yang sulit dibuktikan walaupun pada kasus tersebut telah dilakukan pemeriksaan dan pengumpulan barang bukti yang lengkap. Pasal 285 tentang pemerkosaan berbunyi : Barang siapa dengan kekerasan atau dengan ancaman kekerasan memaksa orang perempuan di luar perkawinan bersetubuh dengan dia karena salahnya perkosaan, dihukum dengan hukuman penjara selama- lamanya dua belas tahun. Jadi harus dibuktikan terlebih dahulu adanya suatu persetubuhan. Bila persetubuhan tidak bisa dibuktikan, maka janggal bila dikatakan suatu perkosaan. Suatu pembuktian yang jelas bahwa telah terjadi suatu persetubuhan secara medis adalah mendapatkan sperma laki-laki di liang senggama wanita yang dimaksud. Beberapa hal yang perlu diketahui adalah bahwa: (a) sperma hidup dapat bertahan selama 3x24 jam dalam rongga rahim; (b) sperma mati dapat bertahan selama $7 \times 24$ jam dalam rongga rahim. Dapat dibayangkan adanya kesulitan bila terjadi suatu overspel, maksudnya antara persetubuhan yang diduga dan waktu pemeriksaan terdapat lagi persetubuhan dengan suaminya sendiri, sehingga sperma yang ditemukan tidak diketahui milik siapa. Dalam kasus-kasus seperti ini, ilmu forensik dapat digunakan untuk mengungkap pelaku kejahatan seksual. ${ }^{6,7}$

Teknik ilmu forensik biasa digunakan pada kejahatan yang lebih serius seperti perkosaan dan pembunuhan. Perkembangan teknologi seperti pembuatan database DNA dan sistem pencarian sidik jari secara automatis telah memberikan perubahan yang sangat besar dalam bidang teknik forensik untuk membantu penyelidikan kejahatan. Perkembangan ini telah membahwa perubahan secara keseluruhan dalam proses penyelidikan suatu kasus. ${ }^{6}$

Dalam upaya pembuktian hukum bahwa telah terjadi tindak pidana perkosaan, maka dalam hal ini Ilmu Kedokteran Forensik sangat berperan dalam melakukan pemeriksaan dan untuk memperoleh penjelasan atas peristiwa yang terjadi secara medis. Dalam pemeriksaan kasus perkosaan dilakukan oleh Polri selaku penyidik untuk mendapatkan barang bukti dan selanjutnya pemeriksaan korban diserahkan oleh dokter forensik untuk 
memeriksa korban perkosaan yang sudah meninggal sedangkan untuk korban perkosaan yang masih hidup diperiksa oleh Dokter Spesialis Kebidanan dan Penyakit Kandungan (Obgyn) dimana hasil pemeriksaannya dituangkan dalam Visum et Repertum yang berguna untuk pembuktian perkosaan di persidangan sebagai alat bukti surat ataupun sebagai keterangan ahli apabila dokter tersebut diminta hadir di persidangan., 2,79

Keadilan dan kemerdekaan seringkali tergantung pada laboratorium forensik yang dapat dipercaya. Kesalahan analitik dapat berarti kebebasan bagi yang bersalah dan penahanan bagi yang tidak bersalah. Laboratorium forensik dapat memperbaiki dan memerintahkan sistem regulator yang akan membawa perbaikan. 1,10,11 $^{10}$

Berdasarkan hal tersebut maka penulis terdorong untuk mengadakan penelitian tentang Peran Ilmu Kedokteran Forensik Dalam Pembuktian Tindak Pidana Pemerkosaan Sebagai Kejahatan Kekerasan Seksual.

\section{TATA LAKSANA ILMU KEDOKTERAN FORENSIK PADA KASUS KEKERASAN SEKSUAL}

\section{A. Persiapan di Tempat Kejadian Perkara}

Tindakan pada kasus/disangka kasus perkosaan atau perzinahan: ${ }^{12}$

1. Perhatikan apakah korban memerlukan pertolongan pertama akibat kekerasan yang dideritanya. Perhatikan juga apakah korban telah cukup umur atau belum selanjutnya lihat skema persetubuhan;

2. Perhatikan apakah pada tubuh korban terdapat tanda-tanda kekerasan

3. Amankan tempat kejadian dan barang bukti
4. Kumpulkan barang bukti sebaikbaiknya seperti noda darah, bercak pada kain, celana, sprei, dan lain-lain

5. Perhatikan sikap korban, apakah takut, gelisah, malu atau tenang-tenang saja.

6. Perhatikan caranya berpakaian dan berhias, adalah berlebihan atau mengandung gairah

7. Kirimkan korban/tersangka korban ke rumah sakit pemerintah dengan formulir visum et repertum model IV tanpa diperkenankan membersihkan badan dahulu. Korban diantar oleh petugas polisi

8. Jelaskan kepada ahli kebidanan/dokter yang bertugas tentang maksud pemeriksaan ini.

9. Bila dipandang perlu maka korban dapat diisolasi dengan pengawasan ketat dan tidak boleh ditemui seorang pun atau berhubungan dengan tamu/keluarga.

\section{B. Pengumpulan Alat Bukti di Tempat Kejadian Perkara}

Untuk kepentingan penyidikan, alat bukti sangat penting. Pengumpulan alat bukti dilakukan di tempat kejadian perkara, selanjutnya alat bukti tersebut dikirim ke laboratorium forensik untuk dianalisis. Barang bukti/material kimia, biologik dan fisik yang ditemukan ditempat kejadian perkara dapat berupa:

1. Material kimia: alkohol, obat-obatan, atau bahan kimia lain yang ditemukan di tempat kejadian perkara

2. Material fisik: serat pakaian, selimut, kain penyekap korban dll.

3. Material biologik: cairan tubuh, air liur, semen/sperma, darah, rambut dll. ${ }^{2,4,11-14}$ 


\section{Persiapan Sebelum Pemeriksaan Korban}

Sebelum korban dikirim ke rumah sakit/fasilitas kesehatan untuk dilakukan pemeriksaan dokter, perlu dijelaskan dengan hati-hati proses pemeriksaan forensik dengan memaparkan langkahlangkah penyelidikan.

Sebelum pemeriksaan forensik syarat yang harus dipenuhi adalah: ${ }^{1,13-15}$

1. Harus ada permintaan tertulis untuk pemeriksaan kasus kekerasan seksual dari penyidik atau yang berwenang.

2. Korban datang dengan didampingi polisi/penyidik.

3. Memperoleh persetujuan (inform consent) dari korban.

4. Pemeriksaan dilakukan sedini mungkin untuk mencegah hilangnya alat bukti yang penting bagi pengadilan.

\section{Pemeriksaan Korban Kekerasan Seksual}

Yang perlu diperiksa oleh dokter terhadap korban/tersangka korban kekerasan seksual sedapat mungkin memenuhi tuntutan yang digunakan dalam undang-undang hukum pidana.

Pemeriksaan fisik juga didasarkan pada kebijakan juridiksional, dan dilakukan oleh dokter dengan pemeriksaan meliputi:

Umum: ${ }^{16}$

1. Rambut, wajah, emosi secara keseluruhan

2. Apakah korban pernah pingsan sebelumnya, mabuk atau tanda-tanda pemakaian narkotik.

3. Tanda-tanda kekerasan diperiksa di seluruh tubuh korban.
4. Alat bukti yang menempel ditubuh korban yang diduga milik pelaku.

5. Memeriksa perkembangan seks sekunder untuk menentukan umur korban.

6. Pemeriksaan antropometri; tinggi badan dan berat badan

7. Pemeriksaan rutin lain

Khusus: ${ }^{16}$

1. Genitalia: pemeriksaan akibat-akibat langsung dari kekerasan seksual yang dialami korban, meliputi:

a. Kulit genital apakah terdapat eritema, iritasi, robekan atau tanda-tanda kekerasan lainnya.

b. Eritema vestibulum atau jaringan sekitar

c. Perdarahan dari vagina.

d. Kelainan lain dari vagina yang mungkin disebabkan oleh infeksi atau penyebab lain.

e. Pemeriksaan hymen meliputi bentuk hymen, elastisitas hymen, diameter penis. Robekan penis bisa jadi tidak terjadi pada kekerasan seksual penetrasi karena bentuk, elastisitas dan diameter penis.

f. Untuk yang pernah bersetubuh, dicari robekan baru pada wanita yang belum melahirkan

g. Pemeriksaan ada tidaknya ejakulasio dalam vagina dengan mencari spermatozoa dalam sediaan hapus cairan dalam vagina

2. Pemeriksaan anal

Kemungkinan bila terjadi hubungan seksual secara anal akan menyebabkan luka pada anal berupa robekan, ireugaritas, keadaan fissura. ${ }^{13}$

3. Pemeriksaan laboratorium 
a. Pemeriksaan darah

b. Pemeriksaan cairan mani (semen)

c. Tes kehamilan

d. Pemeriksaan lain seperti hepatitis, gonorrhea, HIV.

e. Pemeriksaan cairan tubuh, mani, liur, atau rambut yang dianggap pelaku. ${ }^{13,16}$

\section{E. Wawancara/Anamnesis Korban Kekerasan Seksual}

Wawancara dengan korban meliputi empat elemen: Wawancara teraupetik, wawancara investigasi, wawancara medis dan wawancara medico-legal. Walaupun isi dari masingmasing wawancara bisa saling tumpang tindih dan perbedaan wawancara dalam beberapa hal dapat dilakukan oleh orang yang sama, dengan tujuan dan fungsi masing-masing berbeda. Wawancara dapat dilakukan tersendiri, bersahabat dan lingkungan yang mendukung. Penginterview akan membangun suatu hubungan dengan korban dan mulai dengan pertanyaan umum yang tidak berhubungan dengan kekerasan seksual yang dialami, seperti riwayat medis. Jika diperlukan dapat digunakan penerjemah. Bahasa dan nama penerjemah yang digunakan dapat dicatat dalam laporan. Pada kasus remaja, mereka diijinkan untuk didampingi oleh orang tua bila mereka mau. Mereka juga diperlakukan dengan cara yang sama seperti orang dewasa.

\section{F. Pemeriksaan Fisik Korban Kekerasan Seksual}

Pemeriksaan pasien dibagi dalam beberapa kategori yaitu; keadaan umum dan tingkah laku pasien; keadaan tubuh secara keseluruhan, genitalia externa, vagina dan servix, dan anus serta rektum.

\section{G. Penilaian Dugaan Kekerasan Seksual}

Berikut ini detail penilaian kekerasan seksual yang dapat menguatkan terjadinya kekerasan seksual pada korban.

\section{Trauma non genital (kekerasan, bukti menguatkan)}

Trauma fisik adalah pembuktian terbaik adanya kekerasan dan harus selalu didokumentasikan melalui foto, dideskripsikan melalui gambar dan dalam bentuk laporan tertulis. Bukti trauma dapat juga menguatkan pernyataan korban akan kejadian tersebut. ${ }^{1}$

c. Pola trauma non genitalia

Peneliti forensik harus banyak mengetahui tentang pola trauma yang terjadi karena kekerasan seksual, untuk dapat menanyakan pertanyaan yang tepat dan lokasi trauma berdasarkan cerita korban.

Tempat yang paling sering mengalami trauma pada korban kekerasan seksual, termasuk:

- Memar pada tungkai atas dan paha

- Memar pada leher karena cekikan

- Memar pukulan pada lengan atas

- Memar karena postur bertahan pada sisi lengan luar

Juga yang sering adalah: ${ }^{28,29,30}$

- Trauma menyerupai cambuk atau tali pada punggung korban

- Trauma pukulan atau gigitan pada payudara dan puting susu

- Trauma pukulan pada abdomen

- Trauma Pukulan dan tendangan pada paha

- Memar, lecet, dan laserasi pada wajah. 
d. Trauma non genital yang terpola

Istilah "trauma terpola" berbeda dari istilah yang sama, "pola trauma" yang disebutkan diatas. Keduanya penting dalam istilah forensik, akan tetapi, "trauma terpola" adalah trauma dari objek yang digunakan untuk menimbulkan trauma, yang mudah diindentifikasi melalui pola yang ada pada korban.

\section{Bukti trauma genital (kontak seksual, kekerasan)}

Trauma genital menunjukkan adanya kontak seksual dan kekerasan. Trauma genital paling banyak terlihat setelah kekerasan seksual.

Akan tetapi, pada kasus kekerasan seksual seringkali tidak ditemukan bukti trauma genital. Dengan demikian, tidak adanya trauma genital tidak dapat diinterpretasikan bahwa hubungan seks yang terjadi atas persetujuan. Dengan kata lain, peneliti forensik seringkali tidak menemukan bukti trauma genital, dan alasan mengapa ini terjadi harus dijelaskan di pengadilan. ${ }^{28,29,30}$

a. Pola trauma genital

- posterior fourchette (70\%)

- vagina (11\%)

- labia minora (53\%)

- perineum $(11 \%)$

- hymen (29\%)

- area periuretral (9\%)

- fossa navicularis (25\%)

- labia majora (7\%)

- anus (15\%)

- rektum (4\%)

- servix (13\%

b. Hubungan antara trauma non-genital dan trauma genital

- Korban trauma non-genital juga mengalami trauma genital.

- Pada studi lain dari 304 korban kekerasan seksual, 79\% mereka dengan trauma non-genital juga memperlihatkan bukti adanya trauma genital.

d. Bukti dari kolposkopi

Diduga bahwa pemeriksaan kolposkopi untuk memperjelas jaringan genital adalah aset penting untuk identifikasi trauma genital. ${ }^{28,29,30}$

e. Toluidin blue

Toluidine blue adalah nuclear stain yang biasa digunakan dalam pemeriksaan kekerasan seksual untuk mendekteksi adanya mikrotrauma. 28,29,30

f. Deskripsi trauma genital

Trauma biasanya ditemukan dalam pemerkosaan yang disebabkan oleh tidak adanya respon human, yaitu: ${ }^{28,29,30}$

- Tidak adanya kemiringan pelvik untuk mempersiapkan penetrasi

- Tidak adanya bantuan pasangan dengan memasukkan penis atau objek lain.

- Tidak adanya lubrikasi

- Tidak adanya relaksasi

- Peningkatan kekuatan dari penetrasi

- Disfungsi seksual pria

- Tidak adanya komunikasi

H. Evaluasi, Penanganan dan Konseling Korban Perkosaan

1. Evaluasi dan penanganan infeksi akibat transmisi seksual

2. Evaluasi dan Pencegahan Resiko Kehamilan

3. Konseling intervensi krisis dan follow up

4. Penanganan korban pada pusat layanan primer

5. Penanganan korban di rumah sakit provinsi/daerah

\section{ASPEK-ASPEK \\ PENATALAKSANAAN FORENSIK \\ PADA KASUS PERKOSAAN DAN \\ KEKERASAN SEKSUAL}




\section{A. Dasar Perlindungan Terhadap Korban Tindak Pidana Perkosaan}

Dasar perlindungan hukum terhadap perempuan korban kekerasan terdapat dalam UU No. 7 Tahun 1984 Tentang Pengesahan Konvensi Mengenai Penghapusan segala Bentuk Diskriminasi Terhadap Wanita (Convention On The Elimination of All Forms of Discrimination Against Women-CEDAW) yang menyatakan: ${ }^{21,22}$

Perlindungan hukum terhadap korban kekerasan terhadap perempuan (perkosaan) dituangkan juga dalam Kepres No. 181 Tahun 1998 Tentang Komisi Nasional Anti Kekerasan Terhadap Perempuan. ${ }^{21,23}$

\section{B. Landasan Hukum untuk Jaminan Perlindungan dari Tindak Kekerasan Seksual}

Nasional

1. Kitab Undang-undang Hukum Pidana (KUHP) Pasal 285, 286, 287, 290, 291

2. UU No.23 tahun 2004 tentang Penghapusan Kekerasan Dalam Rumah Tangga (PKDRT) Pasal 8(b), 47, 48

3. UU No 21 tahun 2007 Tentang Pemberantasan Tindak Pidana Perdagangan Orang pasal $1(3,7)$

4. UU No.23 Tahun 2002 tentang Perlindungan Anak pasal 1(15), 17(2), 59 dan 66 (1,2), 69, 78 dan 88

Internasional

1. Statuta Roma Pasal 7 ayat 2 (g), Pasal 69 ayat $1 \& 2$, Pasal 68

2. Resolusi PBB 1820 tentang Kekerasan Seksual dalam Konflik Bersenjata

3. Deklarasi penghapusan tindak kekerasan terhadap perempuan (ICPD) pada bulan Desember 1993

\section{Deklarasi Wina Tahun $1993 .{ }^{24}$}

\section{Masalah penegakan hukum terhadap kekerasan berbasis gender}

1. Imunitas terhadap bentuk-bentuk penyiksaan berbasis jendergender: perkosaan dan pelecehan seksual. ${ }^{22}$

2. Hukum pidana Indonesia menerapkan sebuah definisi perkosaan yang sudah usang dan tidak lagi memenuhi standar internasional. Perkosaan didefinisikan secara sempit dan eksklusif dalam bentuk penetrasi paksa organ-0rgan seksual. Menurut Kitab Undang-Undang Hukum Acara Pidana Indonesia (KUHAP), penanganan kasus perkosaan menuntut adanya bukti air mani yang dikuatkan oleh catatan medis (visum et repertum) dan pernyataan dari dua sumber, termasuk seorang saksi.

3. UU Indonesia No. 26 tahun 2000 tentang pengadilan HAM menerapkan definsi peka jendergender dari Statuta Roma atas kejahatan HAM yang mengakui kekerasan berbasis genjer dan perbudakan seksual. Namun, karena Indonesia belum meratifikasi dan mengintegrasikan Statuta Roma secara keseluruhan, termasuk prosedur dan aturan pembuktiannya, maka pihak perempuan yang telah mengalami kekerasan seksual dalam konteks serangan luas dan sistematik atas populasi sipil masih belum juga mendapat akses pada keadilan. Pada saat ini, UU Pengadilan HAM hanya dapat diterapkan dengan menggunakan KUHP dan KUHAP yang tidak kondusif untuk keadilan bagi perempuan.

4. Indonesia tidak memiliki peraturan hukum yang memidanakan pelecehan seksual. 
5. Adanya pembatasan yang ketat dan pembisuan dalam peraturan pidana mengenai pelecehan seksual dan perkosaan dalam kerangka kerja hukum Indonesia dapat dikatakan memberi impunitas terhadap bentukbentuk utama penyiksaan yang berbasis jendergender

\section{Visum et Repertum}

Untuk kasus terkait percabulan atau perkosaan, biasanya menggunakan salah satu alat buktinya berupa Visum et repertum. Visum et repertum adalah surat keterangan/laporan dari seorang ahli mengenai hasil pemeriksaannya terhadap sesuatu, misalnya terhadap mayat dan lain-lain dan ini dipergunakan untuk pembuktian di pengadilan. ${ }^{23,24}$

\section{E. Upaya Perlindungan Hukum pada Korban Tindak Pidana Perkosaan}

Deklarasi Perserikatan BangsaBangsa No.40/A/Res/34 Tahun 1985 telah menetapkan beberapa hak korban (saksi) agar lebih mudah memperoleh akses keadilan, khususnya dalam proses peradilan pidana. Meskipun pada tahun 1984 telah diratifikasi Konvensi tentang Penghapusan Diskriminasi Terhadap Perempuan dengan Undang-Undang No. 7 Tahun 1984 (karena kebijakan umum serta berbagai peraturan yang ada saat ini masih mencerminkan kuatnya nilai patriarki), tetapi dalam pelaksanaannya masih terjadi diskriminasi dan eksploitasi. ${ }^{23,24}$

Perlindungan hukum terhadap korban tindak pidana perkosaan dilakukan sebagai berikut: $:^{24,25}$

1. Sebelum Sidang Pengadilan.

\section{Selama Sidang Pengadilan. \\ 3. Setelah sidang pengadilan.}

\section{PENUTUP}

\section{A. Kesimpulan}

Perkosaan adalah tindakan kekerasan seksual yang merupakan kejahatan terhadap hak asasi manusia yang memberikan dampak fisik dan psikologis yang berat bagi korban dan keluarga.

Pembuktian kasus perkosaan sangat sulit dilakukan meskipun bukti-bukti telah dikumpulkan. Pasal 285 menuntut adanya tanda-tanda persetubuhan untuk menentukan apakah terjadi pemerkosaan. Dalam keadaan ini, Ilmu Forensik dapat digunakan untuk mengungkap pelaku kejahatan seksual.

Forensik merupakan alat bukti sah dalam memberikan keyakinan hakim untuk memutuskan tersangka/terdakwa bersalah dan/atau tidak bersalah.

Ilmu forensik menjelaskan identitas (siapa) tersangka yang melakukan kejahatan; tipe (apa) kejahatan yang dilakukan; waktu (kapan) insiden terjadi; lokasi (dimana/tempat kejadian perkara); modus operandi (bagaimana) pelanggaran terjadi; serta motif dibalik kejahatan.

Landasan hukum di Indonesia terhadap kekerasan seksual: Persetubuhan (pasal 284, 285, 286, 287, 288, 293, 294); Luka/kekerasan (pasal 285, 288); Luka berat (pasal 286, 287, 288); Pingsan/tidak berdaya (pasal 285, 286).

Bukti fisik kekerasan seksual terdiri dari dua tipe: bukti fisik dan laboratorium. Bukti-bukti ini harus dikumpulkan dan diperiksa dengan hati-hati agar tidak mengaburkan pelaku tindak pidana pemerkosaan.

Pemeriksaan rutin laboratorium forensik meliputi: urine untuk tes 
kehamilan, screening penyakit menular, dll.

Pembuktiaan kasus perkosaan saat ini menggunakan DNA, dengan sampel pemeriksaan dapat diambil dari berbagai sumber seperti, air liur, spermatozoa, darah, kulit ataupun keringat.

Penatalaksanaan kedokteran forensik pada kasus kekerasan seksual meliputi: persiapan ditempat kejadian perkara; Pengumpulan alat bukti di tempat kejadian perkara; pemeriksaan korban dan tersangka/dugaan tersangka; dan penilaian dugaan kasus kekerasan seksual.

Dasar hukum perlindungan korban tindak pidana perkosaan adalah UU No 7 tahun 1984 tentang Pengesahan Konvensi Mengenai Penghapusan segala Bentuk Diskriminasi Terhadap Wanita (Convention On The Elimination Of All Forms Of Discrimination Against WomenCEDAW). Kemudian ditungkan dalam Kepres No. 181 tahun 1998 Tentang Komisi Nasional Anti Kekerasan Terhadap Perempuan.

Di Indonesia diatur oleh Kitab Undang-undang Hukum Pidana (KUHP) Pasal 285, 286, 287, 290, 291; UU No.23 tahun 2004 tentang Penghapusan Kekerasan Dalam Rumah Tangga (PKDRT) Pasal 8(b), 47, 48; UU No 21 tahun 2007 Tentang Pemberantasan Tindak Pidana Perdagangan Orang pasal 1 (3,7). UU No.23 Tahun 2002 tentang Perlindungan Anak pasal 1(15), 17(2), 59 dan 66 (1,2), 69, 78 dan 88.

Masalah penegakan hukum untuk tindak pidana pemerkosaan yaitu; hukum pidana Indonesia menerapkan sebuah definisi perkosaan yang sudah usang dan tidak lagi memenuhi standar internasional. Perkosaan didefinisikan secara sempit dan eksklusif dalam bentuk penetrasi paksa organ-0rgan seksual dengan menuntut adanya bukti air mani yang dikuatkan oleh catatan medis (visum et repertum) dan pernyataan dari dua sumber, termasuk seorang saksi. Persyaratan hukum membuat perempuan korban perkosaan mustahil mendapat keadilan melalui jalur hukum.

\section{B. Saran}

1. Perlu sosialisasi pada masyarakat perlunya menjaga dan tidak merusak barang bukti di tempat kejadian perkara, atau pada bagian tubuh korban agar memudahkan pemeriksaan forensik untuk menemukan pelaku kekerasan.

2. Revisi undang-undang mengenai kekerasan seksual sehingga dapat memberikan jaminan hukum dan melindungi sepenuhnya korban kekerasan seksual.

3. Perlu dilakukan pelatihan bagi penyedia layanan kesehatan bagaimana penanganan korban kasus perkosaan, bagaimana mengamankan alat bukti pemerkosaan.

\section{DAFTAR PUSTAKA}

1. Prodjodikoro W. Tindak-tindak pidana tertentu di Indonesia. Refika aditama. Edisi 3. 2003. p 118-9

2. Bradbury SA., Feist A. The use of forensic science in volume crime investigations: a review of the research literature. Home office online report. Crime Reduction and Community Safety Group. 2005

3. Abdussalam HR. Forensik. Restu Agung. Jakarta. Edisi 3. 2006. p 139-149.

4. Narejo NB., Avais MA. Examining the Role of Forensic Science for the Investigative -Solution of Crimes. Sindh university research journal. 
Science series. Vol.44. 2012. p 251-254

5. Gaensslen RE., Lee HC. Sexual Assault Evidence: National Assessment and Guidebook. US Department of Justice. Januari 2002.

6. West Virginia SAFE. Sexual assault forensic medical examination. Training and Collaboration Toolkit-Serving Sexual Violence Victims with Disabilities. Sexual Violence 101

7. Murtika IK., Prakoso D. Dasar-dasar ilmu kedokteran kehakiman. Cetakan ke-2. 1992. p 110-112

8. Ernoehazy W., et.al. sexual assault. Medscape refference. August, 2012.

9. Ledray LE. Evidence collection and care of the sexual assault survivor. The SANE-SART response. Violence against women online resource. August, 2001.

10. Friedman, R.D. 'Assessing Evidence' 94 Michigan Law Review 1810.

11. Gastwirth, J.L. (1988a) Statistical Reasoning in Law and Public Policy, vol 1: Statistical Concepts and Issues of Fairness. Boston, Mass.: Academic Press.

12. Jonakait, RN. Forensic science: the need for regulation. Volume 4, spring issue. 1991. p 109-191.

13. Muller K. Forensic science in medicine: what every doctor should know. CPD. 2003. p 41-5

14. Stark MM. Medical Forensic Medicine A Physician's Guide. $2^{\text {nd }}$ Edition. New Jersey : Humana Press Inc. 2005.

15. Philip SL. Clinical Forensic Medicine : Much Scope for Development in Hong Kong. Hongkong : Department of Pathology Faculty of Medicine University of Hong Kong. 2007.

16. Aitken C. Robert P. Jackson G. Probability and Statistical Evidence in Criminal Proceedings. Fundamentals of Probability and Statistical Evidence in Criminal Proceedings. Guidance for Judges, Lawyers, Forensic Scientists and Expert Witnesses. Practitioner guide No 1.

17. Fienberg, S. E. The Evolving Role of Statistical Assessments as Evidence in the Courts. New York: Springer. 1989

18. Finkelstein, M. Basic Concepts of Probability and Statistics in the Law. New York: Springer. 2009.

19. National policing improvement agency. Guidance on investigating and proscecuting rape. Abridged edition. 2010.

20. Hobbs CJ, Hanks HGI, Wynne JM: Violence and criminality. Dalam: Child Abuse and Neglect A Clinician's Handbook. 2nd Edition. Churchill Livingstone, London. 1999.

21. Wahid A., Muhammad I. Perlindungan Terhadap Korban Kekerasan Seksual : Advokasi Atas Hak Asasi Perempuan, Bandung, Refika Aditama, 2001, hal 82-83

22. Laporan Perwakilan Khusus Sekertaris General PBB untuk Pembela HAM, misi ke Indonesia, Januari 2008. A/HRC/7/28/add.2

23. Dikdik M. Arief Mansur-Elisatris Gultom, Urgensi Perlindungan Korban Kejahatan-Antara Norma dan Realita, Jakarta, PT. RadjaGrafindo Persada, 2007.

24. Ihromi O, Sulistyawati Irianto, Achie S, Luhulima., Pengahpusan Diskriminasi Terhadap Perempuan, Penerbit Alumni Bandung, 2000.

25. Moerti Hadiati Soeroso., Kekerasan Dalam Rumah Tangga Dalam Perspektif Yuridis-Viktimologis, Sinar Garfika, Jakarta, 2010 
26. R. Sugandhi, Kitab Undang-Undang Hukum Pidana dengan Penjelasannya, Surabaya, Usaha Nasional, 1980.

27. Romli Atmasasmita, Kapita Selekta Hukum Pidana dan Kriminologi, Bandung, Mandar Maju, 1992.

28. Lonsway KA. Successfully investigating acquaintace sexual assault: A National Training Manual for law enforcement. The national centre for women and policing. May 2001

29. Lowa department of public health. Medico-legal aspect of sexual offences. Chapter 11. 2011

30. Gilmore T., et al. Sexual assault: a protocol for adult forensic and medical examination. Lowa department of public health. June, 2011. 